\title{
Intuitive eating in youth: Its relationship with nutritional status
}

\author{
Alimentação intuitiva na juventude: sua relação \\ com o estado nutricional
}

\author{
Saniye BILICI ${ }^{1}$ iD 0000-0002-1235-0329 \\ Betul KOCAADAM ${ }^{1}$ iD 0000-0002-9058-4630 \\ Hande MORTAS ${ }^{1}$ (iD) 0000-0001-6356-5226 \\ Ozge KUCUKERDONMEZ2 ID 0000-0003-2228-8917 \\ Eda KOKSAL ${ }^{1}$ iD 0000-0002-7930-9910
}

A B S T R A C T

\section{Objective}

To determine intuitive eating in young adults and the effects of factors such as gender, Body Mass Index and dietary intake, and dietary adequacy on intuitive eating.

\section{Methods}

This cross-sectional study was conducted with students at Gazi University in Ankara (N=665; 17.6\% men; $82.4 \%$ women). The questionnaire, including the general characteristics, anthropometric measurements, Intuitive Eating Scale-2, and 24-H Dietary Recall sections, were applied to all participants. For the evaluation of the diet, Nutrient Adequacy Ratio and Mean Adequacy Ratio were used.

\section{Results}

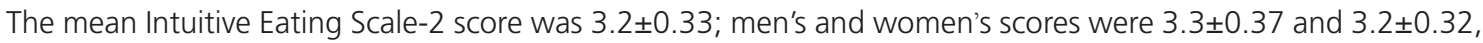
respectively $(p<0.05)$. According to linear regression analysis, gender, age and mean adequacy ratio had an effect on the model for the score $(p<0.05)$. In addition, there was a negative correlation between Intuitive Eating Scale-2 scores and Body Mass Index values in women $\left(r_{p}=-0.095, p=0.026\right)$.

\footnotetext{
1 Gazi University, Faculty of Health Sciences, Department of Nutrition and Dietetics. Emniyet Mahallesi, Muammer Yaşar Bostancı Caddesi, 16, Beşevler, Ankara, Turkey. Correspondencia para/Correspondence to: B KOCAADAM. E-mail: <betulkocaadam@gmail.com>.

2 Ege University, Faculty of Health Sciences, Department of Nutrition and Dietetics. İzmir, Turkey.
}

Como citar este artigo/How to cite this article

Bilici S, Kocaadam B, Mortas H, Kucukerdonmez O, Koksal E. Intuitive eating in youth: Its relationship with nutritional status. Rev Nutr. 2018;31(6):557-65. http://dx.doi.org/10.1590/1678-98652018000600005 


\section{Conclusions}

The intuitive eating scores varied according to gender, dietary adequacy and age. Intuitive eating may be effective in the formation of long-term behavioral changes, which is beneficial for the treatment of obesity. The result of this study may encourage the development of this behavior in groups (may vary according to gender), that is thought to be effective by considering the changes of intuitive eating behavior.

Keywords: Intuitive eating. Behavioral change. Body mass index. Nutrient Adequacy Ratio. Mean Adequacy Ratio.

\section{R E S U M O}

\section{Objetivo}

Determinar a alimentação intuitiva em adultos jovens e os efeitos de fatores como sexo, índice de massa corporal, ingestão alimentar e adequação da dieta na alimentação intuitiva.

\section{Métodos}

Este estudo transversal foi realizado em estudantes da Universidade de Gazi, em Ancara ( $N=665 ; 17,6 \%$ homens; 82,4\% mulheres). O questionário, incluindo as características gerais, medidas antropométricas, Escala de Alimentação Intuitiva 2 e recordatório alimentar de 24 horas foi aplicado aos participantes. Para a avaliação da dieta, foram utilizados o Índice de Adequação de Nutrientes e a Razão de Adequação Média.

\section{Resultados}

A Escala Média de Escala de Comportamento Intuitivo-2 foi de 3,2 $\pm 0,33$, dos homens e das mulheres, foi de $3,3 \pm 0,37$ e 3,2 $\pm 0,32$, respectivamente $(p<0,05)$. De acordo com a análise de regressão linear, sexo, idade a Razão de Adequação Média tiveram efeito no modelo formado pelo escore $(p<0,05)$. Além disso, houve uma correlação negativa entre os escores da Escala de Alimentação Intuitiva-2 e os valores do índice de massa corporal nas mulheres $\left(r_{p}=-0,095, p=0,026\right)$.

\section{Conclusão}

Os escores alimentares intuitivos variaram de acordo com o gênero, com adequação da dieta e com a idade. A alimentação intuitiva pode ser eficaz na formação de mudanças a longo prazo no comportamento, o que é benéfico para o tratamento da obesidade. O resultado deste estudo pode encorajar o desenvolvimento deste comportamento em grupos (talvez variar de acordo com o gênero) que é considerado efetivo considerando-se as mudanças do comportamento alimentar intuitivo.

Palavras-chave: Alimentação intuitiva. Mudança de comportamento. Índice de massa corporal. Índice de Adequação de Nutrientes. Razão de Adequação Média.

\section{NTRODUCTION}

In recent years, obesity as a result of unhealthy eating habits, and sedentary lifestyle have become a major public health problem especially in young adults in Turkey as well as worldwide $[1,2]$. The primary approach to treat obesity is to provide the patient with weight loss through diet and exercise [3]. However, increasing evidence suggests that the efficacy of this treatment method is questionable in long term [4].

As an alternative to energy-restricted diets, the movement to shape eating based on the intuition of individuals began in the 1980s and has continued to the present day. This movement defends the limited effectiveness of diet restriction (restrictive eating, avoiding food, limiting energy intake) in the long run [5]. Tribole \& Resch [6] developed the concept of "intuitive eating " based on the philosophy of nutrition to define healthy eating and behaviors. Intuitive eating is a new dietary approach that rejects the dieting mentality [7]. Intuitive eating is defined as the way of eating food by listening to and adapting to physical hunger, satiety, and satiety signals naturally given by the individual's body. The concept of intuitive eating is also 
characterized by concepts such as normal eating, adaptive eating, wisdom eating and conscious eating [8].

The Intuitive Eating Scale (IES) was first introduced to the scientific literature by Hawks et al. [9]. The scale was then developed and the Intuitive Eating Scale-2 (IES 2) was developed [10]. Baş et al. [11] determined the validity and reliability of IES-2 in Turkish university students.

According to the results presented in a literature review assessing the relationship between intuitive eating and health measures, it is stated that there is a positive relationship among intuitive eating, psychological health measures and positive eating behaviors, but a negative one between intuitive eating and the body mass index (BMI) [4]. Similarly, most current work on intuitive eating has shown that it was related to lower rigid control, lower psychological distress, higher psychological adjustment, and lower BMI [12]. Clinical studies have shown that intuitive eating does not have much effect on body weight loss, but it is effective in terms of weight maintenance, improved psychological health, positive physical health indicators (e.g. blood pressure, cholesterol level etc.) and diet intake and/or eating behaviors [13-16]. In addition to these findings, studies assessing the relationship between $\mathrm{BMI}$ and intuitive eating have found negative correlations between the two $[5,17]$. To the best of our knowledge, this study is important in that it is the first study in Turkey after the validity and reliability study. Corroborating the study of Baş et al. [11], the present study offers: the relationship between intuitive eating and BMI, dietary intake and dietary adequacy.

\section{METHODS}

This cross-sectional study was conducted with 665 university students in Gazi University between the ages of 18-25 years, who agreed to participate in the study voluntarily (September-November 2017) and live in Ankara, the capital city of Turkey (the response rate of the study was 75\%). Because some of the individuals participating in the research could not be reached, participants were selected by probabilistic sampling. GPower version 3.1.9.2 (University of Düsseldorf, Düsseldorf, Germany) was used to perform calculations on sample size within an 85\% confidence interval at a 0.05 significance level, and sample size calculation indicated a sample size of 615 individuals.

The questionnaire form was applied to the participants using the face-to-face interview method. Verbal or written consents of individuals participating in the research were obtained by the voluntary consent form in accordance with the Helsinki declaration. This study was approved by the Research Ethics Committee of Gazi University. The questionnaire consists of general characteristics, anthropometric measures, Intuitive Eating Scale-2, and 24-h dietary recall (for 2 days, weekday and weekend) sections.

In order to assess the intuitive eating score, the Turkish version of the Intuitive Eating Scale-2 (5-point Likert scale instrument with twenty-three items), developed by Baş et al. [11], was used. In this validity and reliability study, Bartlett's test of sphericity yielded a value of X2=9043.49 ( $p<0.001)$, while the Kaiser-MeyerOlkin index was 0.87 . The IES-2 consists of four subscales: 1. Unconditional permission to eat (UPE; 6 items; e.g., "If Im craving a certain food, I allow myself to have it"), Eating for physical reasons (EPR; 8 items; e.g., "I mostly eat foods that make my body perform efficiently (well)"), Reliance on hunger and satiety cues (RHSC; 6 items; e.g., "I rely on my hunger signals to tell me when to eat"), and Body-food choice congruence (B-FCC; 3 items) (e.g., "I mostly eat foods that give my body energy and stamina") was used for each item, participants respond using a 5-point scale that ranges from 1 (strongly disagree) to 5 (strongly agree). To score the IES-2, negative items are reverse coded and then added to a composite score, which is then divided by the number of items to obtain a mean score. 
The researchers asked the participants to talk about their dietary intake over a 2-day period (weekday and weekend) using the 24-h dietary recall method. Nutrition Information Systems (Beslenme Bilgi Sistemi-BeBiS/The German Food Code and Nutrient Data Base, BLS II.3, 1999) which is a food software program in compliance with Turkish food, was used to assess energy (kcal), macronutrients, and micronutrients. For the evaluation of dietary adequacy, the Nutrient Adequacy Ratio (NAR) and Mean Adequacy Ratio (MAR), which is measured by NAR, were used.

\section{Nutrient Adequacy Ratio (NAR)}

NAR was calculated using the daily intake ratio of a nutrient and Dietary Reference Intake (DRI) framework categorized according to age and gender. In this study, NAR were obtained for a total of twelve nutrients (protein, fiber, vitamin $\mathrm{B}_{6}$, folate, vitamin $\mathrm{B}_{12}$, vitamin $\mathrm{C}$, calcium, phosphor, potassium, magnesium, iron and zinc) [18].

$$
\operatorname{NAR}(\%)=\frac{\text { Daily intake of a nutrient } \times 100}{\text { DRI amount of the nutrient }}
$$

\section{Mean Adequacy Ratio (MAR)}

MAR was obtained by ratio of the total NARs divided by the number of nutrients (for twelve nutrients). For both NAR and MAR, a value of $100 \%$ is the ideal since it means that the intake is the same as the requirement [18].

$$
\operatorname{MAR}(\%)=\frac{\sum \text { NAR }(\%)}{\text { Number of nutrients }}
$$

Participants' weight and height measurements were taken by the researchers in accordance with the measurement techniques [19]. Body mass index is calculated as the weight $(\mathrm{kg})$ divided by squared height $\left(\mathrm{m}^{2}\right)$. The World Health Classification (WHO) reference values were used in the classification of BMI [20].
The obtained data were evaluated using SPSS 22.0 statistic package program (SPSS Inc., Chicago, Illinois, United States). Baseline sample characteristics, including sociodemographic data, dietary intake, NAR, MAR, total IES-2 score and its subscales, and the BMI were analyzed using descriptive statistics and are presented as means and standard deviation for continuous variables and as percentages for categorical variables. Chi-square was used to compare categorical variables. One-way Anova (with Tukey's (HSD) - Honestly Significant Difference test - for post hoc comparison) and Student's t-test were used for statistical analysis. To identify the correlation among the parameters, Pearson correlation analysis was used.

Linear regression was used to determine the relationships of IES-2 score with gender, age, BMI, energy, and MAR. The results were evaluated within a $95 \%$ confidence interval and at $p<0.01$ and $p<0.05$ significance level.

\section{RES U L T S}

This study was conducted with 665 university students $(17.6 \%$ men; $82.4 \%$ women) whose mean age was $20.9 \pm 1.76$ (between 18-25 years). The mean BMI was found for men was $23.3 \pm 2.67 \mathrm{~kg} / \mathrm{m}^{2}$ and $21.5 \pm 2.89 \mathrm{~kg} / \mathrm{m}^{2}$ for women $(p<0.001)$. Most men $(68.4 \%)$ and women $(72.8 \%)$ had normal BMI. There were no significant differences between energy and macronutrient intake (carbohydrates, protein, fat) in men and women. The mean energy intake was $2235.8 \pm 1058.9 \mathrm{kcal} /$ day (men: $2318.3 \pm 940.6$; women: $2218.2 \pm 1082.49 \mathrm{kcal} /$ day). Overall, the mean IES-2 score was $3.2 \pm 0.33$, men's score was $3.3 \pm 0.37$, while women's score was $3.2 \pm 0.32$. Regarding gender, the total IES-2 scores and its subscale scores were found to be significantly different $(p<0.05)$ (Table 1$)$. The mean MAR was $83.8 \pm 14.1$ (men: $83.2 \pm 13.8$, women: $83.9 \pm 14, p>0.05$ ) (Table 2).

There was no relationship between the IES-2 score and its subscales and daily total energy, macronutrient intake and MAR ( $p>0.05)$ 
Table 1. Descriptive data of the individuals. Ankara, Turkey, 2017.

\begin{tabular}{|c|c|c|c|c|c|c|c|}
\hline \multirow{2}{*}{ Characteristics of the individuals } & \multicolumn{2}{|c|}{ Men (n:117) } & \multicolumn{2}{|c|}{ Women (n:548) } & \multirow[b]{2}{*}{$p^{*}$} & \multicolumn{2}{|c|}{ Total (N:665) } \\
\hline & Mean & SD & Mean & SD & & Mean & SD \\
\hline Age (years) & 21.3 & 1.68 & 20.8 & 1.77 & $0.012^{*}$ & 20.9 & 1.76 \\
\hline BMI $\left(\mathrm{kg} / \mathrm{m}^{2}\right)$ & 23.3 & 2.67 & 21.5 & 2.89 & $0.000^{*}$ & 21.8 & 2.94 \\
\hline Energy (kcal) & 2318.3 & 940.61 & 2218.2 & 1082.49 & 0.354 & 2235.8 & 1058.90 \\
\hline Carbohydrates (g) & 270.3 & 114.36 & 252.4 & 111.19 & 0.116 & 255.5 & 111.87 \\
\hline Protein (g) & 81.8 & 36.83 & 74.8 & 37.34 & 0.063 & 76.0 & 37.32 \\
\hline Fat (g) & 97.8 & 43.66 & 98.3 & 78.70 & 0.941 & 98.2 & 73.72 \\
\hline $\begin{array}{l}\text { Eating for Physical Rather than } \\
\text { Emotional Reasons }\end{array}$ & 3.3 & 0.49 & 3.1 & 0.51 & $0.001^{*}$ & 3.1 & 0.51 \\
\hline Unconditional Permission to Eat & 3.1 & 0.49 & 3.0 & 0.50 & $0.002^{*}$ & 3.0 & 0.50 \\
\hline Reliance on Hunger and Satiety Cues & 3.1 & 0.92 & 3.3 & 0.61 & $0.039^{*}$ & 3.3 & 0.67 \\
\hline Body-Food Choice Congruence & 3.8 & 0.81 & 3.6 & 0.86 & $0.015^{*}$ & 3.6 & 0.86 \\
\hline Total IES-2 score & 3.3 & 0.37 & 3.2 & 0.32 & $0.001^{*}$ & 3.2 & 0.33 \\
\hline BMI classification & $\mathrm{n}$ & $\%$ & $\mathrm{n}$ & $\%$ & $p^{\beta}$ & $n$ & $\%$ \\
\hline Underweight & 4 & 3.40 & 81 & 14.80 & $0.000^{\beta}$ & 85 & 12.80 \\
\hline Normal & 80 & 68.40 & 399 & 72.80 & & 479 & 72.00 \\
\hline Overweight & 32 & 27.40 & 62 & 11.30 & & 94 & 14.10 \\
\hline Obese & 1 & 0.80 & 6 & 1.10 & & 7 & 1.10 \\
\hline
\end{tabular}

Note: Independent Sample $t$-test $p^{*}<0.05$; Chi-square: $p^{\beta}<0.01$.

BMI: Body Mass Index (kg/m²); IES-2: Intuitive Eating Scale-2; SD: Standard Deviation.

(data not shown). Negative correlations were found between the IES-2 score, Unconditional Permission to Eat score and $\mathrm{BMI}$ for women ( $r=-0.095, p=0.026 ; r=-0.108, p=0.011$, respectively). Body-Food Choice Congruence score was negatively associated with BMI in both women and in total $(p<0.05)$. There was a negative relationship between MAR and BMI for both genders, but these were not statistically significant (Table 3).

The difference between the mean scores of the IES-2 scores and its subscales according to the BMI classification was found to be significant only for the Body-Food Choice Congruence score $(p=0.026)$. This score was significantly higher in underweight individuals than in normal individuals $(3.9 \pm 0.82 ; 3.6 \pm 0.84$, respectively; $p=0.15$ ) (data not shown).

When factors that could affect the IES-2 score (age, gender, energy, MAR, and BMI) were evaluated using linear regression analysis, models were deemed important $\left(R^{2}: 0.030\right)$ $p<0.01)$. Although, BMl and energy were not significantly related to the IES-2 score ( $p>0.05)$, age, gender and MAR had an effect in the model for the score $(p<0.05)$ (Table 4).

\section{DISCUSSION}

The results of this study showed that the intuitive eating score varied according to gender. The total IES-2 score and its subscales (except for Reliance on Hunger and Satiety Cues score) for women were significantly lower. Similarly, Tylka et al. [12] reported that men scored significantly higher in the IES-2 when compared to women. In one study, adolescent sex differences for intuitive eating has been examined, reporting that girls were more likely than boys to manage their emotions through eating [21]. In another 
study of college undergraduates, women scored lower on Eating for Physical Reasons; they were also less attuned to their bodies' signals about hunger and fullness than men [10]. However, this study shows that women remain more attuned to their bodies regarding hunger and fullness than men. This can be explained by the fact that girls learn at a young age to associate eating with relief from negative emotions, which may be caused by the pressures they experience from parents regarding what, when, and how much to consume [22], On the other hand, in some studies, gender was not related to the intuitive eating score [23-25].

Although this study was conducted on undergraduates, age was found to be an important factor for intuitive eating. In a study, participants over the age of 22 tended to score higher on intuitive eating; on the other hand, it has been stated that demographic factors such as age and year in college were less clearly associated with intuitive eating values [26]. This result shows that age has a positive effect on intuitive eating. However, this relationship should also be assessed among older age.

It is known that intuitive eating covers the concept of "body wisdom" (the body will instinctively maintain the variety of food needed to sustain health) [4]. Intuitive eaters can be expected to have more nutritious eating habits and more positive eating habits than nonintuitive eaters. Some studies have found that intuitive eating develops positive dietary intake/ eating habits $[16,27]$, but it has been determined that there is no effect in another study whose sample size is low and homogeneous [28]. From this point of view, in the present study, intuitive eating was associated with dietary adequacy. Participants with a high IES-2 score have higher dietary adequacy.

Intuitive eating has been proposed as a healthier, more effective, and more innate alternative to current weight management 
Table 3. Correlation of BMI with dietary intake, MAR and IES-2. Ankara, Turkey, 2017.

\begin{tabular}{|c|c|c|c|c|c|c|}
\hline \multirow{2}{*}{ Dietary intake } & \multicolumn{2}{|c|}{ Men $(n=117)$} & \multicolumn{2}{|c|}{ Women $(n=548)$} & \multicolumn{2}{|c|}{ Total $(\mathrm{N}=665)$} \\
\hline & $r$ & $p$ & $r$ & $p$ & $r$ & $p$ \\
\hline Energy (kcal) & -0.098 & 0.294 & -0.082 & 0.056 & -0.073 & 0.061 \\
\hline Carbohydrate (g) & -0.142 & 0.128 & -0.083 & 0.053 & -0.075 & 0.054 \\
\hline Protein (g) & -0.102 & 0.273 & -0.070 & 0.104 & -0.055 & 0.157 \\
\hline Fat (g) & -0.029 & 0.755 & -0.057 & 0.185 & -0.052 & 0.177 \\
\hline MAR & -0.105 & 0.261 & -0.049 & 0.254 & -0.061 & 0.117 \\
\hline Eating for Physical Rather than Emotional Reasons & -0.035 & 0.705 & -0.061 & 0.154 & -0.023 & 0.547 \\
\hline Unconditional Permission to Eat & 0.062 & 0.508 & -0.108 & $0.011^{*}$ & -0.046 & 0.236 \\
\hline Reliance on Hunger and Satiety Cues & 0.071 & 0.449 & 0.066 & 0.124 & 0.044 & 0.257 \\
\hline Body-Food Choice Congruence & 0.021 & 0.819 & -0.152 & $0.000^{*}$ & -0.098 & $0.012^{*}$ \\
\hline Total IES-2 score & 0.064 & 0.491 & -0.095 & $0.026^{*}$ & -0.032 & 0.406 \\
\hline
\end{tabular}

Note: Pearson Correlation $p<0.05$.

IES-2: Intuitive Eating Scale-2; BMI: Body Mass Index; MAR: Mean Adequacy Ratio.

Table 4. Total IES-2 score linear regression analysis. Ankara, Turkey, 2017.

\begin{tabular}{lccc}
\hline Model & Beta & $t$ & $p$ \\
\hline Total IES-2 score & & & 0.044 \\
Age (year) & 0.078 & 2.017 & 0.001 \\
Gender & -0.135 & -3.397 & 0.106 \\
BMl $\left(\mathrm{kg} / \mathrm{m}^{2}\right)$ & -0.064 & -1.618 & 0.222 \\
Energy (kcal/day) & -0.061 & -1.222 & 0.049 \\
MAR\% & 0.098 & 1.969 & \\
\hline
\end{tabular}

Note: $R^{2}=0.030 ; p=0.001$.

BMI: Body Mass Index (kg/m²); MAR: Mean Adequacy Ratio.

strategies. Substantial and consistent associations between intuitive eating and lower BMI have been reported $[4,29]$. In the present study, it was determined that BMI was inversely related to Body-Food Choice Congruence score. The scores of underweight individuals were significantly higher. These results show that healthy eating habits may be more common in underweight individuals. Furthermore, according to gender, there was a negative relation between the BMI and IES-2 score, specifically Unconditional Permission to Eat and Body-Food Choice Congruence scores in women. On the other hand, there was no significant relationship between BMI and IES-2 score in men unlike the other study conducted by Denny et al. [24]. This can be explained by the low number of men in that study (17.6\%). Young people who are becoming aware of their bodies and being influenced by external messages (e.g., parental pressure about food) may be particularly vulnerable to the effects of dieting on intuitive eating, particularly women. These results support the idea that a low IES-2 score in women may negatively affect weight control. 


\section{CONCLUSION}

In conclusion, age, gender and dietary adequacy have been shown to be an important factor for determining intuitive eating. Moreover, the results of this study indicate an inverse correlation of intuitive eating with the BMI in women. This study shows that intuitive eating has a positive relationship with dietary adequacy. Thus, obesity prevention and treatment strategies have mainly focused on counteracting detrimental dietary behaviors. Considering adaptive behaviors, such as intuitive eating, could be useful for developing behavioral guidelines insisting on incentives rather than restrictions, particularly regarding gender, as the results of this study have shown. Factors affecting intuitive eating need to be investigated in longitudinal studies in future studies.

\section{CONTRIBUTORS}

$S$ BILICI designed the study and wrote the protocol. B KOCAADAM and H MORTAS conducted literature research and provided summaries of previous research studies. E KOKSAL and Ö KUCUKERDONMEZ conducted the statistical analysis and revised the manuscript. All authors contributed to and have approved the final manuscript.

\section{ACKNOWLEDGEMENTS}

The authors thank the participants for their support with the data collection. The authors alone are responsible for the content and writing of the article.

\section{REFERENCES}

1. Karaoglan D, Tansel A. Determinants of obesity in Turkey: A quantile regression analysis from a developing country. 2017 [cited 2017 Sept 15]. Available from: https://ssrn.com/abstract= 2900125

2. Ng M, Fleming T, Robinson M, Thomson B, Graetz $\mathrm{N}$, Margono C, et al. Global, regional, and national prevalence of overweight and obesity in children and adults during 1980-2013: A systematic analysis for the global burden of disease study 2013. Lancet. 2014;384(9945):766-81.

3. Lang A, Froelicher ES. Management of overweight and obesity in adults: Behavioral intervention for long-term weight loss and maintenance. Eur J Cardiovasc Nurs. 2006;5(2):102-14.

4. Van Dyke N, Drinkwater EJ. Review article relationships between intuitive eating and health indicators: Literature review. Public Health Nutr. 2014;17(8):1757-66.

5. Herbert B, Blechert J, Hautzinger M, Matthias E, Herbert C. Intuitive eating is associated with interoceptive sensitivity: Effect on body mass index. Appetite. 2013;70:22-30.

6. Tribole E, Resch E. Intuitive eating: A recovery book for the chronic dieter: Rediscover the pleasures of eating and rebuild your body image. New York: St.Martin's Press; 1995.

7. Anglin JC. Assessing the effectiveness of intuitive eating for weight loss-pilot study. Nutr Health. 2012;21(2):107-15.

8. Akay GG. Yeme bozukluklarında fiziksel açlığı duygusal açlıktan ayırt edebilme. Turkiye Klinikleri J Psychol-Special Topics. 2016;1(2):17-22.

9. Hawks SR, Merrill RM, Madanat HN. The intuitive eating scale: Development and preliminary validation. Am J Health Educ. 2004;35(2):90-9.

10. Tylka TL, Van Diest AMK. The intuitive eating scale-2: Item refinement and psychometric evaluation with college women and men. J Couns Psychol. 2013;60(1):137-53.

11. Baş M, Karaca KE, Saglam D, Arıııcı G, Cengiz $E$, Köksal $S$, et al. Turkish version of the intuitive eating Scale-2: Validity and reliability among university students. Appetite. 2017;18:391-7.

12. Tylka TL, Calogero RM, Daníelsdóttir S. Is intuitive eating the same as flexible dietary control? Their links to each other and well-being could provide an answer. Appetite. 2015;95:166-75.

13. Bacon L, Stern JS, Van Loan MD, Keim LN. Size acceptance and intuitive eating improve health for obese, female chronic dieters. J Acad Nutr Diet. 2005; 105(6):929-36.

14. Provencher V, Bégin C, Tremblay A, Mongeau L, Corneau L, Dodin S, et al. Health-at-every-size and eating behaviors: 1-year follow-up results of a size acceptance intervention. J Am Diet Assoc. 2009;109(11):1854-61.

15. Gagnon-Girouard MP, Bégin C, Provencher $\mathrm{V}$, Tremblay A, Mongeau L, Boivin S, et al. Psychological impact of a 'health-at-every-size' intervention on weight-preoccupied overweight/ obese women. J Obes. 2010;2010:928097. 
16. Hawley G, Horwath C, Gray A, Bradshaw A, Katzer $L$, Joyce $J$, et al. Sustainability of health and lifestyle improvements following a non-dieting randomised trial in overweight women. Prev Med. 2008;47(6):593-9.

17. Anderson L, Erin E, Schaumberg K, Dmochowski $S$, Anderson D. Contributions of mindful eating, intuitive eating, and restraint to $\mathrm{BMI}$, disordered eating, and meal consumption in college students. Eat Weight Disord. 2015;21(1):83-90.

18. Mirmiran P, Azadbakht L, Esmaillzadeh A, Azizi F. Dietary diversity score in adolescents-a good indicator of the nutritional adequacy of diets: Tehran lipid and glucose study. Asia Pac J Clin Nutr. 2004;13(1):56-60.

19. Lohman TJ, Roache AF, Reynaldo M. Anthropometric standardization reference manual. Med Sci Sports Exerc. 1992;24(8):952.

20. World Health Organization. Obesity: Preventing and managing the global epidemic. Geneva: WHO; 2000. WHO Technical Report Series No.894.

21. Dockendorff SA, Petrie TA, Greenleaf CA, Martin S. Intuitive eating scale: An examination among early adolescents. J Couns Psychol. 2012;59(4):604-11.

22. Galloway AT, Farrow CV, Martz DM. Retrospective reports of child feeding practices, current eating behaviors, and BMI in college students. Obesity. 2010;18(7):1330-5.

23. Anglin JC, Borchardt N, Ramos E, Mhoon K. Diet quality of adults using intuitive eating for weight loss-pilot study. Nutr Health. 2013;22(3-4):255-64.
24. Denny KN, Loth K, Eisenberg ME, NeumarkSztainer D. Intuitive eating in young adults: Who is doing it, and how is it related to disordered eating behaviors? Appetite. 2013;60(1):13-9.

25. Gan WY, Yeoh WC. Associations between body weight status, psychological well-being and disordered eating with intuitive eating among Malaysian undergraduate university students. Int J Adolesc Med Health. 2017. Ahead of print. http:dx.doi.org/10.1515/ijamh-2017-0095

26. Hawks SR, Merrill RM, Madanat HN, Miyagawa T, Suwanteerangkul J, Guarin CM, et al. Intuitive eating and the nutrition transition in Asia. Asia Pac J Clin Nutr. 2004;13(2):194-203.

27. Madden CE, Leong SL, Gray A, Horwath CC. Eating in response to hunger and satiety signals is related to BMI in a nationwide sample of 1601 mid-age New Zealand women. Public Health Nutr. 2012;15(12):2272-9.

28. Cole RE, Horacek T. Effectiveness of the "my body knows when" intuitive-eating pilot program. Am J Health Behav. 2010;34(3):286-97.

29. Camilleri GM, Méjean C, Bellisle F, Andreeva VA, Kesse-Guyot E, Hereberg $S$, et al. Intuitive eating is inversely associated with body weight status in the general population-based NutriNet-Santé study. Obesity. 2016;24(5):1154-61.

Received: August 2, 2018

Final version: November 13, 2018

Approved: December 13, 2018 